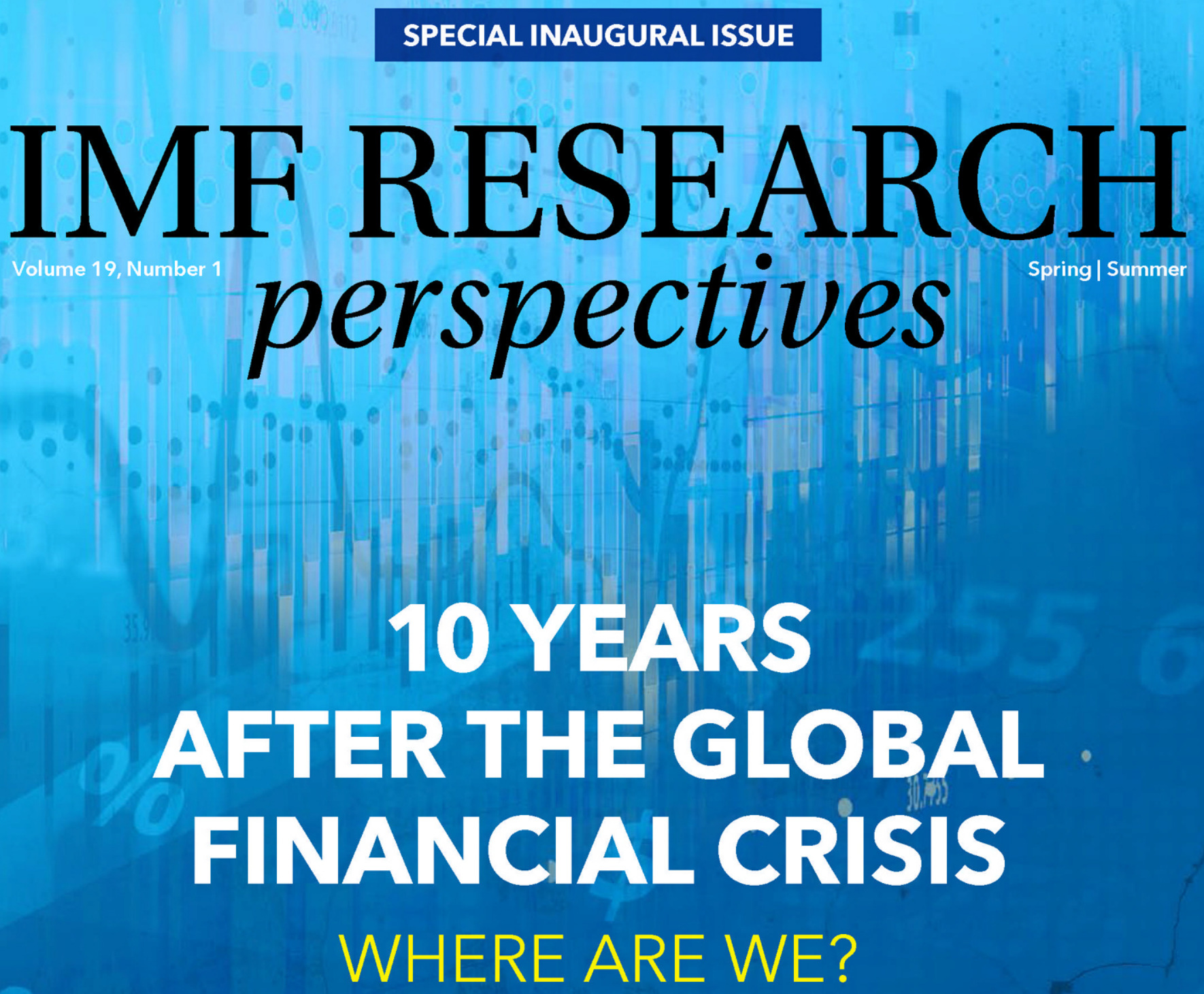

Lessons from the Global Financial Crisis: Interview with Valerie Cerra
The rise of populism: is it really the economy stupid?
Winners v. Losers:

The dilemma of reforms
To BOT, or not to BOT ... that is (no longer) the question

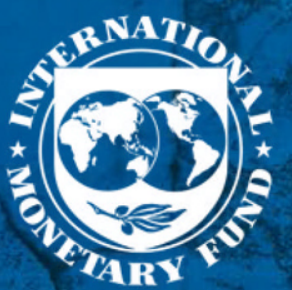

BONUS ARTICLE Can $\{U n\}$ Happiness Explain Macroeconomics? 


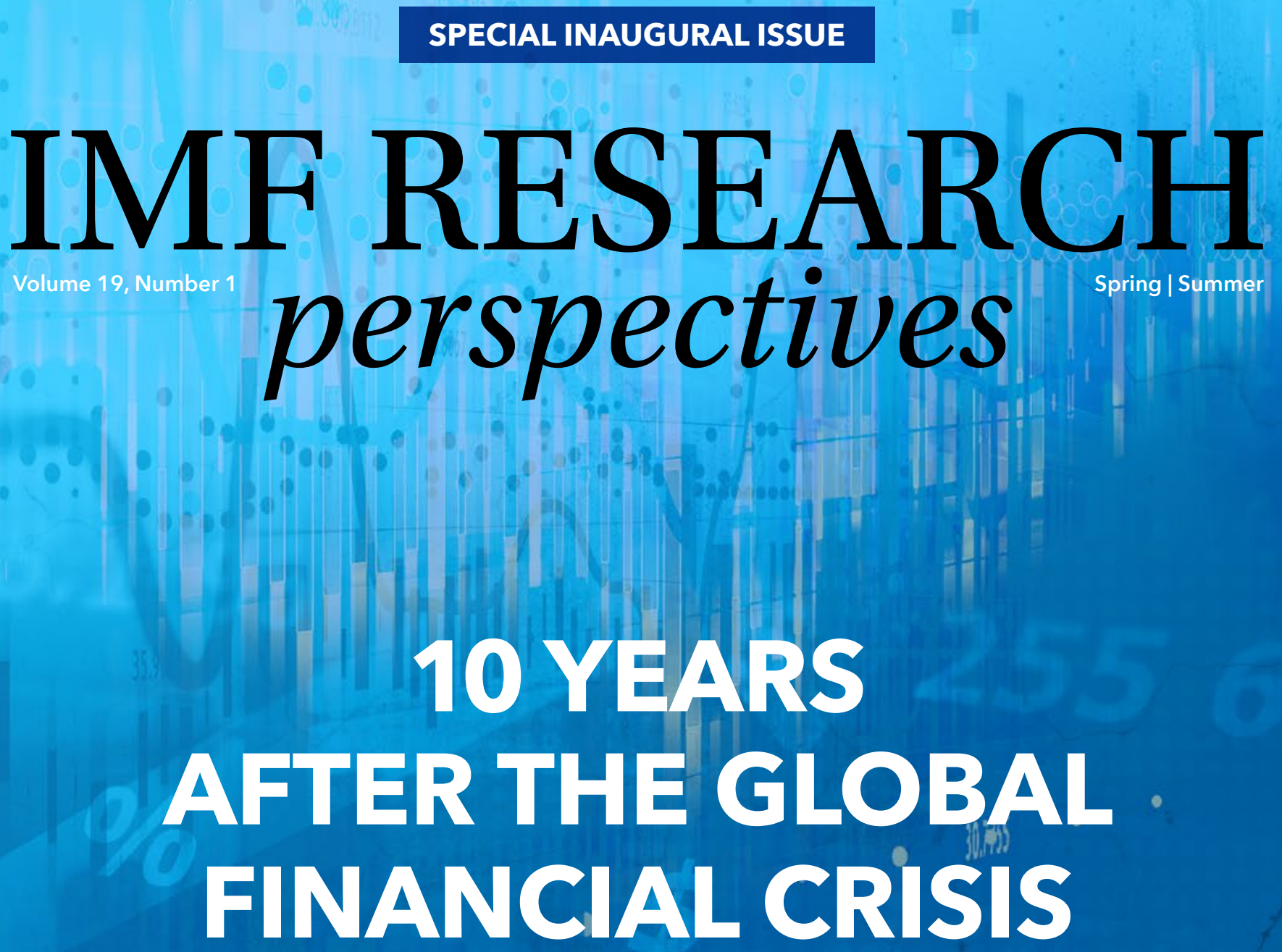

\section{WHERE ARE WE?}

Lessons from the Global Financial Crisis: Interview with Valerie Cerra
The rise of populism: is it really the economy stupid?
Winners v. Losers:

The dilemma of reforms
To BOT, or not to BOT ... that is (no longer) the question
BONUS ARTICLE

Can $\{$ Un $\}$ Happiness

Explain

Macroeconomics?

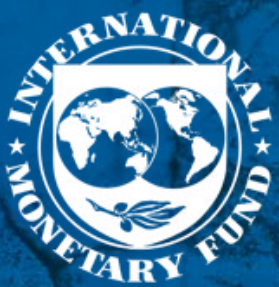

Riding the Big Data

Wave 


\section{IMF RESEARCH perspectives}

\author{
Editors-in-Chief \\ Deniz Igan \\ Chris Papageorgiou \\ Guest Editor \\ Sweta C. Saxena \\ Assistant Editor \\ Patricia Loo \\ Editorial Assistant \\ Tracey Lookadoo \\ Contributors \\ Anthony Annett \\ Hites Ahir \\ Pankhuri Dutt \\ Swarnali A. Hannan \\ Zoltan Jakab \\ Daniela Muhaj \\ Patricia Neidlinger \\ Cover, design, and layout \\ Creative
}

Corporate Services and Facilities

IMF Research Perspectives-the IMF online bulletin with news on research is a bi-annual publication in English and is available exclusively online free of charge.

The views expressed in the Bulletin are those of the author(s) and do not necessarily represent those of the IMF or IMF policy. Material from this publication may be reprinted with proper attribution.

Editorial correspondence may be addressed to: INTERNATIONAL MONETARY FUND Attn: Editor, IMF Research Perspectives 700 19th Street, NW

Room HQ1-9-253

Washington, DC 20431

USA

E-mail: resbulletin@imf.org

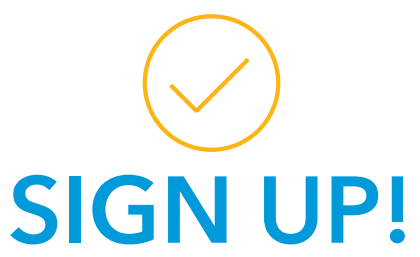

For new issues of the IMF Research Perspectives and a variety of other IMF publication, sign up for an electronic notification at: www.imf.org/external/cntpst

Individual issues are available at www.imf.org/researchbulletin.

\section{CONTENT}

3 Lessons from the Global

Financial Crisis: Interview

with Valerie Cerra

7 The rise of populism: is it really the economy stupid?

9 Winners v. Losers: The dilemma of reforms
11 To BOT, or not to BOT ... that is (no longer) the question

14 Riding the Big Data Wave

16 Can $\{U n\}$ Happiness

Explain Macroeconomics?

\section{Meet IMF Research Perspectives,}

the bulletin with sharper storytelling, richer design, and more

When you read the Spring/Summer 2018 issue of the IMF Research Perspectives (formerly published as IMF Research Bulletin), if we did it right, you will meet the more approachable, more human side of IMF research and IMF researchers.

The bulletin has just turned 18, and we thought this was a good time to revamp the design and content. How? First, we transformed our Q\&A feature into a complete interview. Second, we added more research summaries to give you a better sense of what IMF research has to offer on recent topical issues. Third, we changed the design to make your reading experience more enjoyable and reaching out to the contributors easier. And, of course, we changed the name to Perspectives, which we feel more accurately reflects our new approach focused on sharing views and encouraging interaction. One thing that hasn't changed is our commitment to conduct and disseminate state-ofthe-art, policy-relevant research to foster further discussion for better policymaking around the world.

Such an undertaking would not have been possible without a dedicated group of individuals: the guest editorial team led by Sweta Saxena and the design team led by Felipe Leon deserve the utmost credit.

We hope you will like our fresher, bolder look. Let us know what you think.

Deniz Igan and Chris Papageorgiou

\section{Note from the guest editor}

It has been ten years since the Global Financial Crisis and, around the world, output is yet to fully recover. Moreover, the gains from this slow recovery have largely benefited the relative few, helping to spawn a rise in populist movements in the developed world. The global economy has to confront new challenges from technology and automation (the changing nature of work) and the deployment of big data projects (quality and governance aspects). These portend a better future but also raise fears of further widening the gap between the haves and the have-nots. Perhaps what is missing in this big picture is how the focus of policies can be changed from external values (such as competition, consumption, and profits) to internal values (such as cooperation, compassion, and happiness). The articles in this edition shed light on these issues and how, in the future, economic policies need to evolve to balance tradeoffs and be more supportive and inclusive.

Sweta C. Saxena 


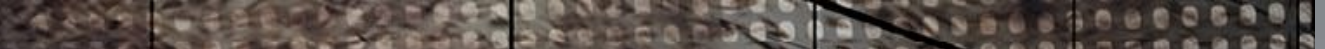

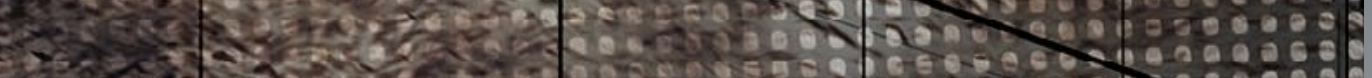

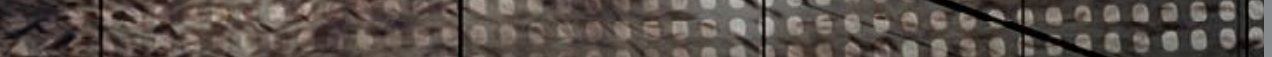

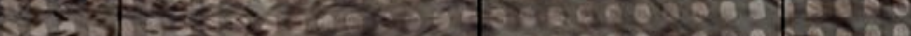

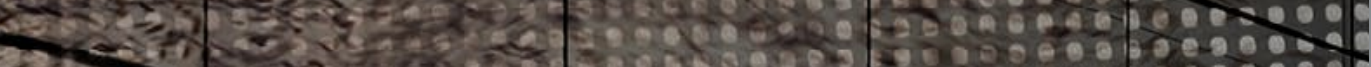

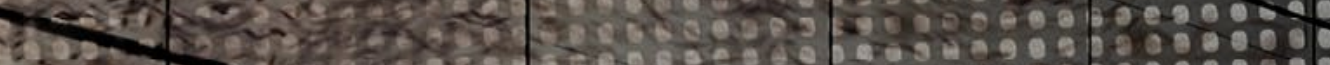

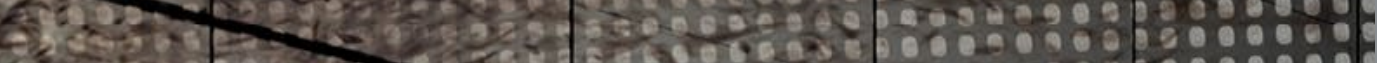

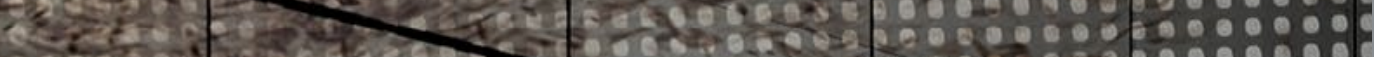

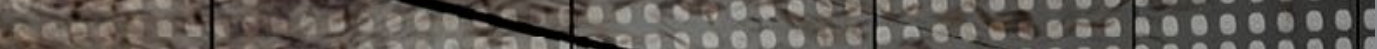

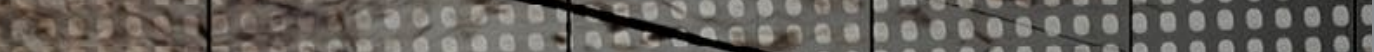

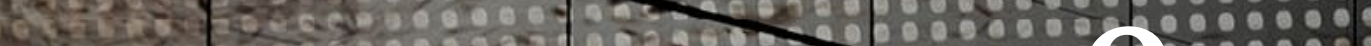

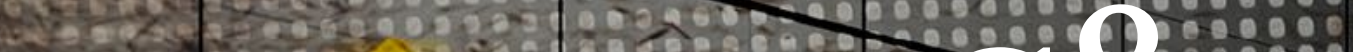

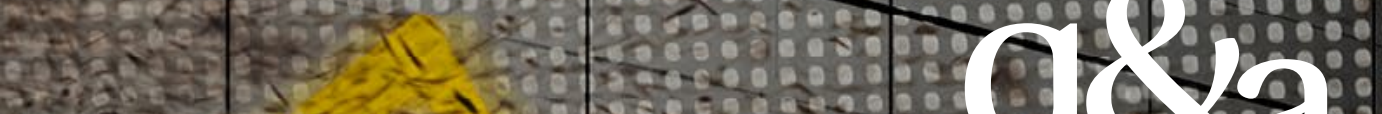

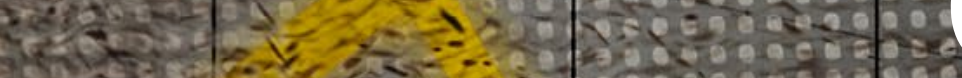

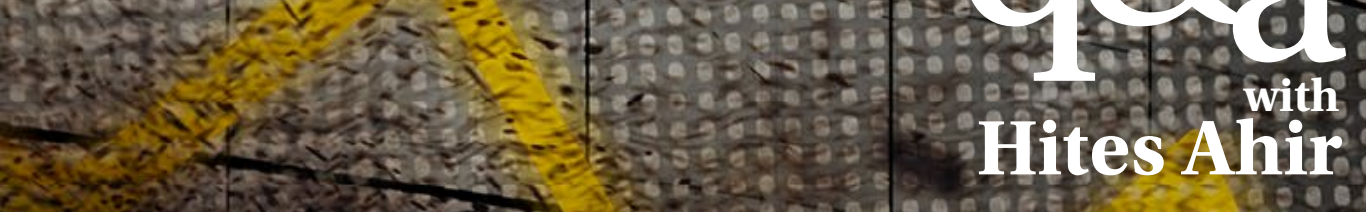

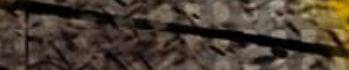

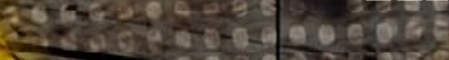
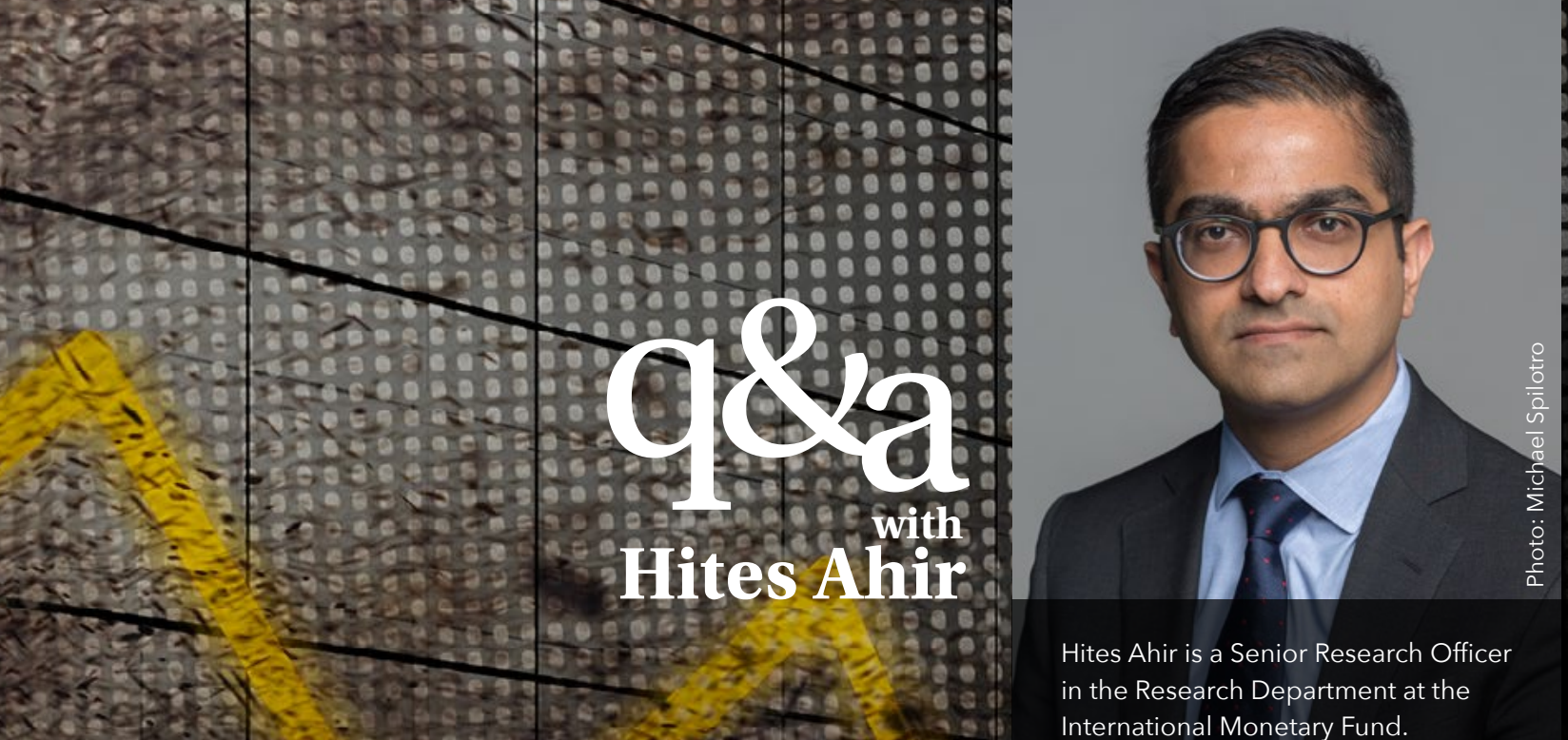
dी

Hites Ahir is a Senior Research Officer in the Research Department at the International Monetary Fund.

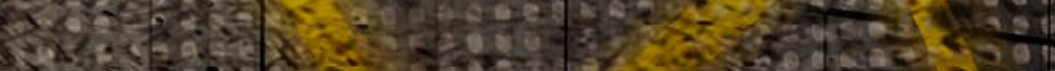

$\checkmark$ hahir@imf.org
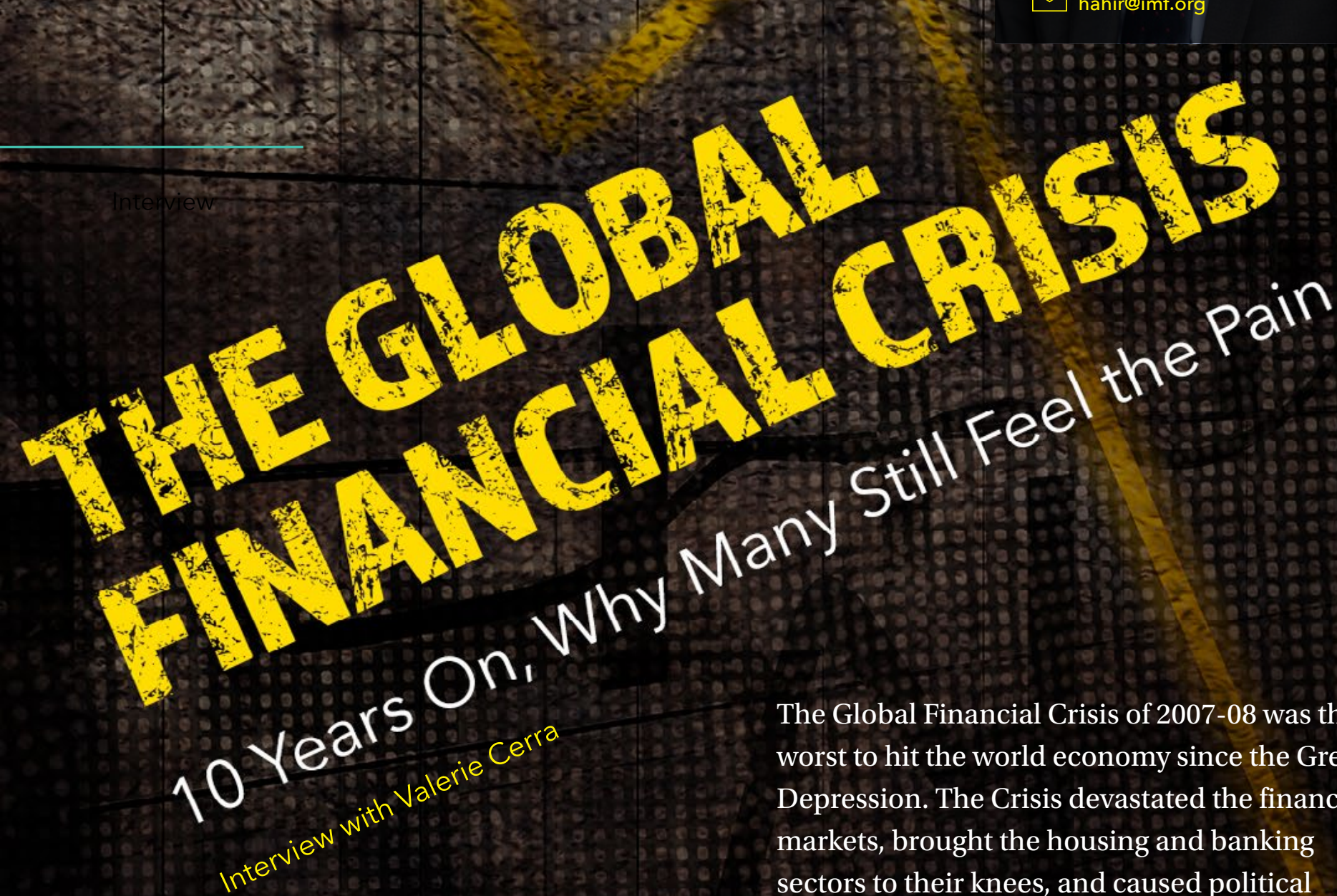

The Global Financial Crisis of 2007-08 was the worst to hit the world economy since the Great Depression. The Crisis devastated the financial markets, brought the housing and banking sectors to their knees, and caused political upheaval in both the developed and developing world. Ten years on from those events, Hites Ahir talks to Valerie Cerra, Assistant Director in the IMF's Institute for Capacity Development, about why some countries still haven't been able to fully recover, what are the implications of recessions and crises for policymaking, and the new stylized model for economic development. 
Hites Ahir: As you know, it is about ten years since the onset of the Global Financial Crisis. A search for "global financial crisis" in Google shows about 14 million results, while Google Scholar shows more than 256,000 results. Do you think we have answered all the questions about the crisis?

Valerie Cerra: In some ways, the global financial crisis shook up the economics profession. At the IMF, we have been accustomed to dealing with crises and other adverse shocks affecting many of our member countries. But the economics profession at large was taken by surprise by the crises in advanced countries. The prevailing assumption had been that economic policy, especially led by central banks, had evolved to maintain economic stability and preserve the "Great Moderation." Some economists also underestimated the role of the financial sector before the crisis. During the past decade, a lot of good work has been done to incorporate financial frictions into our economic models.

Even so, the profession has been much slower to recognize the protracted impact of shocks, sometimes called "hysteresis," or the dependence of the economy on its history. We still don't understand very well why transitory shocks from the financial sector or elsewhere can lead to a persistent fall in productivity, employment, and investment. This poses a fundamental challenge to our theories of the business cycle and economic growth, also calling into question the conventional distinction between "supply shocks" and "demand shocks."
Ahir: After the crisis, some experts predicted a quick economic rebound, while others predicted a slow economic rebound. Could you give us a quick summary of the different views, and the rationale behind them?

Cerra: Most experts, including those responsible for official projections, such as the Council of Economic Advisors, and prominent academics, predicted a quick rebound of economic activity to the pre-crisis trend. They thought GDP growth would be rapid as capacity came back into use and unemployment declined during the economic recovery. Only a minority of experts were skeptical of this optimism, based on their review of historical data.

Ahir: It sounds like you were one of those in the minority. In the paper Booms, Crises, and Recoveries: A New Paradigm of the Business Cycle and its Policy Implications which you co-authored with Sweta Saxena, you argue that crises and recessions tend to permanently depress the level of a country's output. Can you elaborate on that?

Cerra: Our paper debunks the traditional view of the business cycle in which output declines temporarily during a recession and then rebounds quickly to its initial upward trend line during the recovery. Instead, we argue that most recoveries consist only of a return of growth to its long-term expansion rate-without a highgrowth rebound back to the initial trend. In other words, recessions trigger a drop in the trend rather than a deviation from trend.
Ahir: So, you are saying that the business cycle is not actually a cycle? Does the data back up your claim?

Cerra: Correct. Using updated data, we confirm our earlier findings (in IMF WP/05/147) that all types of recessions, on average, lead to permanent output losses, not just those associated with financial and political crises. We also show that countries do not typically have strong growth booms before crises and recessions.

\section{“}

\section{In other words,}

\section{recessions trigger}

\section{a drop in the trend}

\section{rather than a deviation}

\section{from trend.}

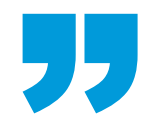

Ahir: In the paper, you also say that the conventional "output gap" is ill-measured and ill-conceived. Why? And what are the pitfalls for monetary and fiscal policymakers if they use this conventional measure?

Cerra: The conventional concept of the "output gap" is intended to represent temporary deviations of output around its long-term trend. But this concept no longer has much meaning if shocks to output move 


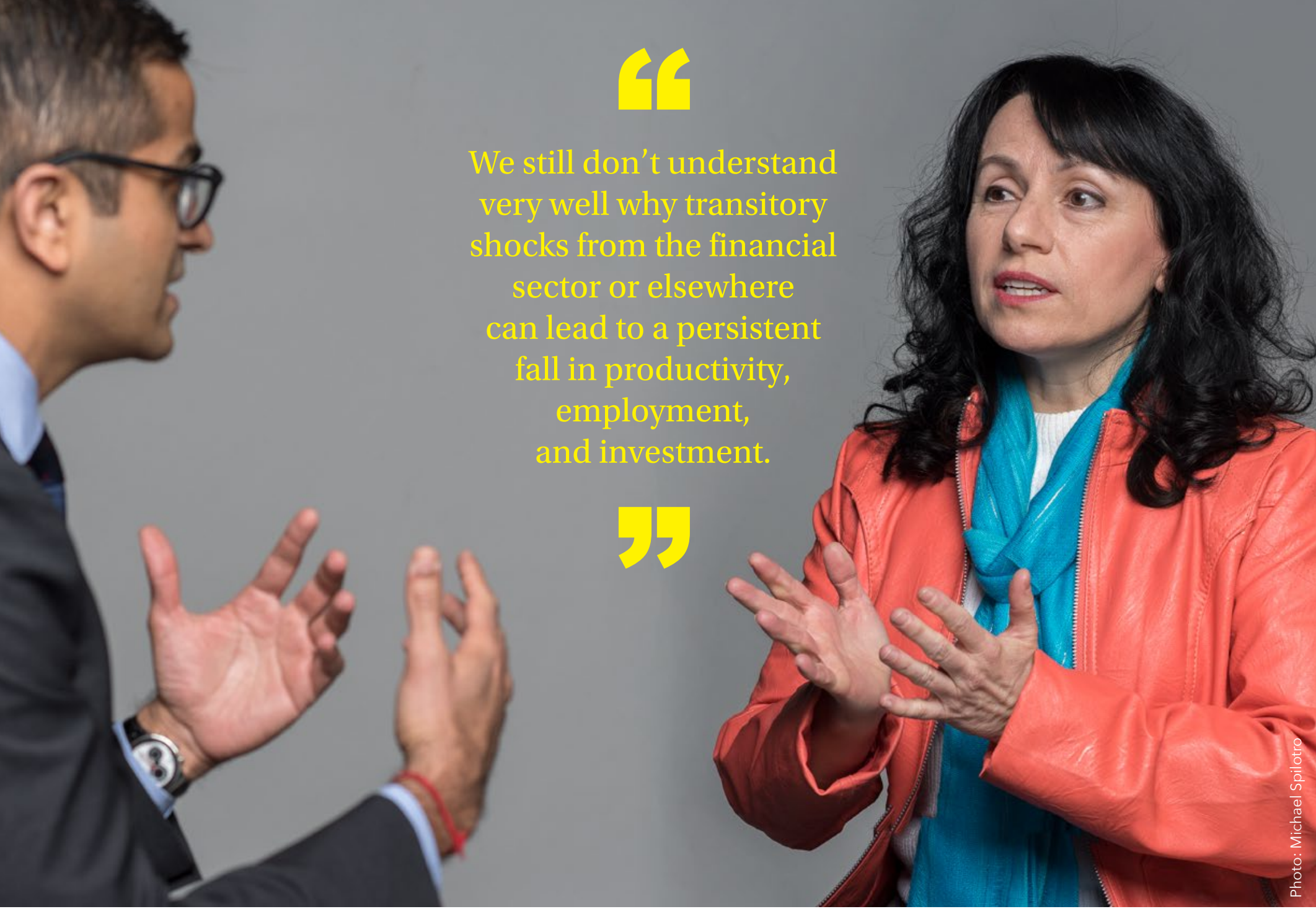

its entire trend. We also show that constructing output gaps by fitting a smooth line through historical GDP data-either by using a simple filter or a more complex structural estimation procedure-leads to spurious cycles and constant revisions to historical estimates. In fact, current estimates of the 2007 output gaps for all of the advanced countries are very positive-implying strong economic booms on the eve of the global financial crisisalthough they were estimated to be small or even negative at the time. This revised view of history is purely a statistical artifact of creating smooth trends through structural breaks, such as permanent output declines, in the GDP data.
Policymakers can face large pitfalls using these conventional output gap concepts and estimates. For example, after a large negative shock, a "cyclically adjusted" fiscal deficit is likely to appear more favorable than the actual deficit. Fiscal authorities may erroneously assume that an expected economic recovery will automatically eliminate the cyclical part of the deficit. But that will not happen if there is no fast rebound and the level of GDPand the associated fiscal revenuesremains below the prior trend. Likewise, central banks should focus on direct measures of inflation pressure rather than on unreliable measures of the output gap.
Ahir: The results of your study point to a new model of long-term economic development. What does this mean for poor countries?

Cerra: We show that poor countries are quite capable of sustaining periods of strong growth and catching up to rich countries, consistent with neoclassical theory. Their failure to do so during the postwar period is largely due to their more frequent and deeper recessions compared with rich countries. Since shocks to output have permanent effects, these frequent and deep recessions drag poor countries down from their convergence paths. 
Ahir: Since the crisis, there has been a lot of talk about regulation, more regulation vs. less regulation, monetary policy, price stability vs. financial stability, and the optimal level of foreign exchange reserves. What do your findings imply for each of these topics?

Cerra: Economic policies should be geared toward avoiding costly crises and severe recessions and building buffers that allow policymakers to respond with appropriate stimulus and safety nets to negative shocks. Policymakers should discourage excessive risk-taking in the financial sector through, on the margin, more regulation than had been imposed before the crisis. Monetary policy may need to play a role in addressing financial stability risks if regulation is insufficient and, at a minimum, should avoid exacerbating asset price and housing bubbles.

Foreign exchange reserves can help insure against losses from adverse external shocks. But the optimal level of reserves may be higher than previously estimated, given our findings that losses associated with crises are persistent rather than temporary. More generally, our work has found that an economic stimulus can help deliver a partial output rebound in the aftermath of a severe recession or crisis. That is, although recessions and crises generate permanent output losses, on average, there is heterogeneity in the outcome that depends on the policy response during the downturn. Thus, countries should build policy space during good times to use as ammunition when facing adverse shocks.
Ahir: There are studies that have linked the large and persistent output losses from financial crises and deep recessions with populist pressure for change, and backlash against globalization. Could you talk a bit about that?

Cerra: Hysteresis from financial crises and deep recessions depress employment and household income, which often leads to populist pressure for policy changes that inadvertently further reduce growth and social welfare. For example, political polarization rises after systemic financial crises (Mian and others, 2014) and far-right political parties earn higher voting shares (Funke and others, 2016). In a negative feedback loop, trade protectionism may rise, which can lower incentives to invest and trade and thus further reduce growth.
Valerie Cerra is an Assistant

Director and Division Chief

of the European and Middle

Eastern Division in the

IMF's Institute for Capacity

Development (ICD). Prior to ICD,

she was in charge of Colombia,

Panama, and Venezuela in the

Western Hemisphere Department

and earlier worked in the African

Department, the IMF Institute,

the European Department,

and the Asia and Pacific

Department. She obtained

undergraduate degrees in

finance and engineering from

the University of Pennsylvania,

and her Ph.D. in Economics from

the University of Washington.

Before graduate school, she was

a financial analyst at a consulting

firm in the U.S. Her research

publications focus on international

macroeconomics, exchange rates,

financial crises, and growth. 


\section{THE RISE}

OF POPULISM:

IS IT really

THE ECONOMY,

\section{STUPID?}

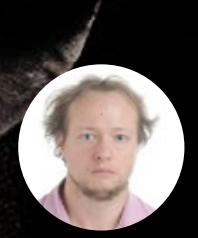

Zoltan Jakab

$\square$ zjakab@imf.org

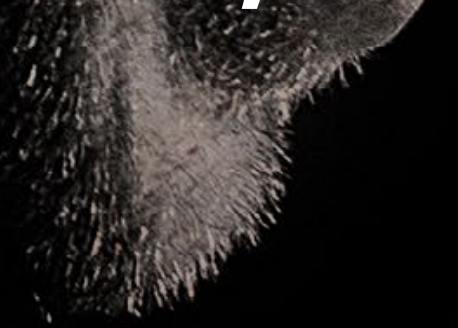

A quick read of the news would have you believe that populism is on the rise following the Great Recession.

At the same time, concerns about inequality loom over policy debates and discussions have focused on the merits and disadvantages of globalization and how certain groups in society have become vulnerable to technological progress. Are these causes related to the rise in populism? 
Populism is a thinly-centered ideology that divides society into homogenous but antagonistic groups-"the people" and the "corrupt elite"-and argues that politics should be the expression of the "people." Populism also claims a moral monopoly over the opposition. The opposite of populism is pluralism and elitism. Pluralism treats the "people" as a diverse group, while elitism treats the elite as "benevolent". However, practical populism should be disentangled from demagoguery, which is simply political rhetoric ignoring budget or resource constraints.

Can the rise in populism be explained by economic developments? One would simply conjecture that a simple macroeconomic model would explain the rise in populism. Take, for example, the HechsherOhlin framework. Here, factor prices change after liberalization, globalization, technological progress, or after a long recession; the owners of factors with lower relative prices lose, while others win. The "losers" are typically lowskilled workers whose jobs are more at risk. In turn, populist politicians can win votes from the "losers" and populism would be on the rise. However, politics is not that simple.

A recent paper by IMF economists challenges this simple economic interpretation. They find little correlation between economic distress and the role of populism in politics at the country and aggregate level in Europe. In fact, populist parties rose in countries less affected by the Great Recession and with relatively robust growth.
However, they also find a positive correlation between regional distress and the vote for populist parties within a country.

"So populism is not just the voice of the losers," says Antonio Spilimbergo, one of the authors of the paper.

"Therefore, perhaps economists need to talk with political scientists to understand populism."

Economic circumstances may determine the demand for populism, but, as we know from economics, the other side of the market for political thought-the supply-is also important. The question still remains why the socalled "losers" in some countries vote for the populists and not for the parties they voted for in the past. The puzzle is confounded by why the less populist traditional parties still satisfy the wishes of voters in many other countries. IMF research finds that economic distress matters only when the level of trust in political institutions is weak. In other words, in countries with low levels of trust, a higher unemployment rate is associated with a greater likelihood of voting for populist parties.

As trust in political institutions increases, voters tend to vote less and less for populist parties, even in periods of economic shock.

What are the consequences of the rise in populism for economic policy? Well, for starters, not all populist movements are created equal. An inclusionary (leftist, socialist) populism would demand an increase in economic regulation, redistribution, and capital taxation. On the other hand, exclusionary (right-wing, nativist) populism would demand less migration and more deregulation.
Is the rise of populism necessarily a bad development? Earlier literature focusing on Latin America was clear that populism was harmful over the longer term. Others, however, claim that the rise of (economic) populism has some merit. While political populism may weaken some checksand-balances and can be harmful, economic populism can sometimes

\section{Iี}

...perhaps economists need to talk with

political scientists to

\section{understand populism.}

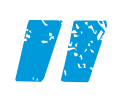

be justified. They put issues on the agenda that might not have been discussed otherwise (for instance, inequality, healthcare, and migration). In a changing world, relaxing the constraints on economic policy and finding newer ways to be more inclusive

$$
\begin{aligned}
& \text { could pave the } \\
& \text { way out of } \\
& \text { the current } \\
& \text { discontent. }
\end{aligned}
$$




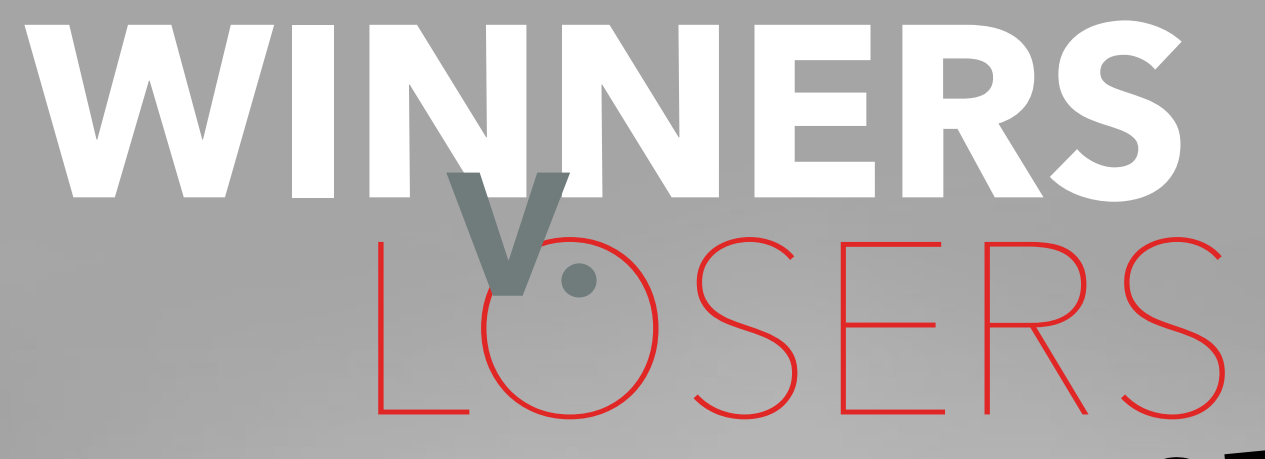

Patricia Neidlinger

$\checkmark$ pneidlinger@imf.org

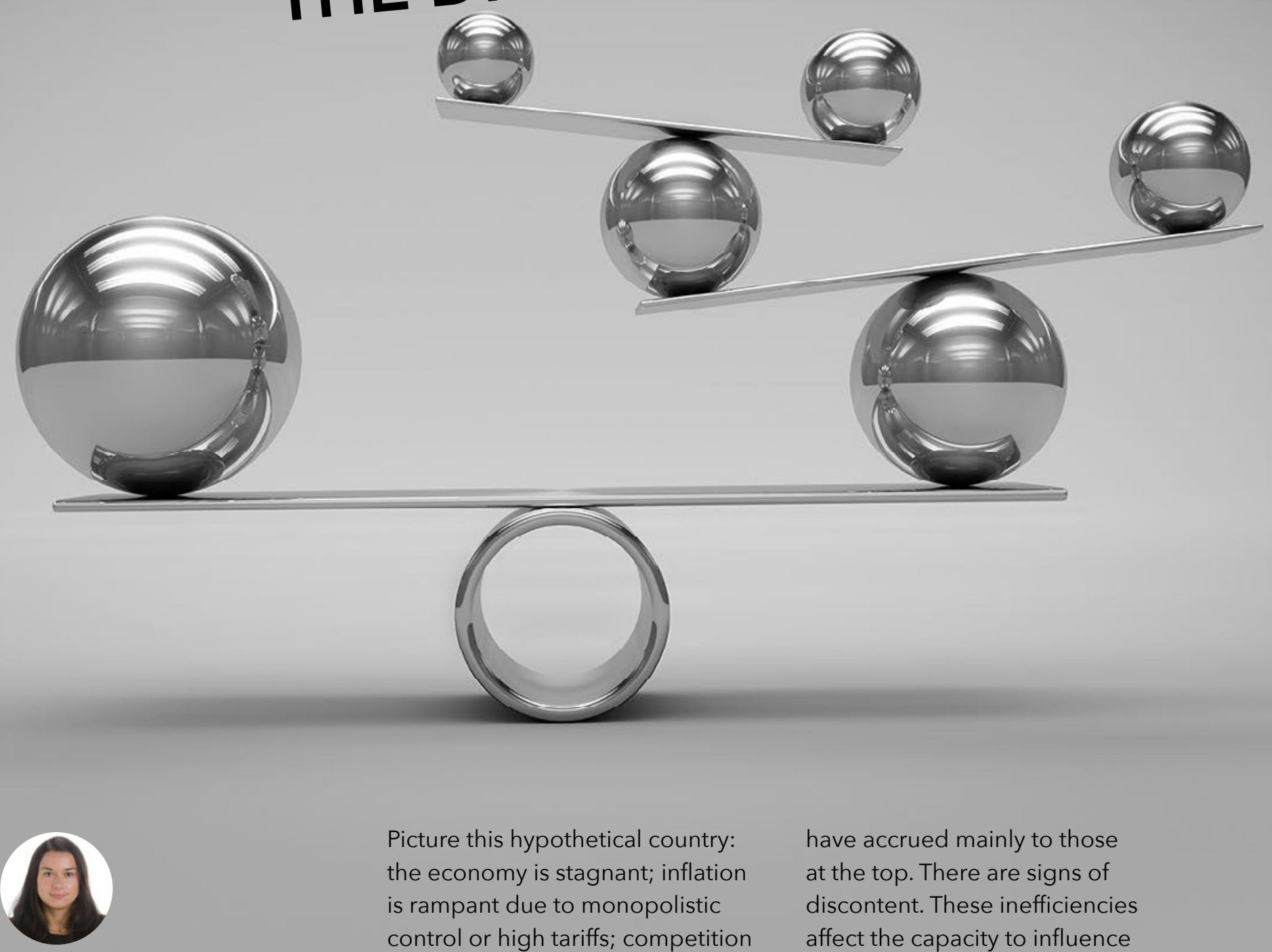

THE DILEMMA OF REFORMS

Picture this hypothetical country: the economy is stagnant; inflation is rampant due to monopolistic control or high tariffs; competition is virtually impossible; access to financial services is limited to a few; the tax system benefits a relatively small group of wealthy and prosperous people; and high and rising income inequality suggests that the benefits of recent growth have accrued mainly to those at the top. There are signs of discontent. These inefficiencies affect the capacity to influence economic change, but addressing them is complicated.

Many real-world countries face a subset, if not all, of these problems, and decisionmakers struggle to address these issues. 
The IMF advocates that structural reforms are a path for economic prosperity: labor and product market reforms lead to a larger pie (GDP), and this potentially benefits everyone. However, more recently, concerns are being voiced about the side effects of some supplyenhancing policies, which generate both winners and losers. In the face of unequal gains (or even absolute losses) from reforms, how can politicians navigate the issue, and even manage to get re-elected given the risk of vocal opposition from the losers?

\section{Recognizing that structural} reforms may generate growthequity tradeoffs, Jonathan Ostry's new paper analyzes the impacts of reforms on both growth and inequality. He finds that a lot depends on what type of reform is being considered. Domestic financial deregulation, external capital market liberalization, and some measures of current account reform increase both growth and inequality. But basic institutional reforms that, for example, strengthen the legal system and popular observance to the law do not seem to generate a growth-equity tradeoff. One reason to be concerned about the impact of reforms on inequality is that higher inequality may actually make growth more fragile (less sustainable): "inequality can be bad for both the level and the sustainability of growth," says Ostry. Some of his earlier work was based on this very topic. This adverse effect on growth will be of concern to those, including the IMF, who emphasize the supply-enhancing effects of reform.

But if reforms can harm a subset of people, should we then roll back the reform agenda? Ostry responds that reform agendas should still proceed-given that their net result is still a sizable aggregate growth dividend-but that the design of reform packages should internalize the distributional effects: "We need to think about a package of reforms that balances winners and losers." A "monopoly" of winners is likely to generate a more unequal society, clearly problematic in situations where inequality is already high. In addition, beyond the ex-ante design of reform packages, Ostry believes that "policymakers should be less shy about using redistributive fiscal policies ex post." His earlier work suggests that, in many cases, redistribution has insignificant efficiency costs and the resulting improvement in equality exerts a protective effect on growth.

Structural reforms are vital for countries to regain and sustain growth momentum, improve labor markets, and ensure the health of domestic markets. However, the tradeoffs with respect to income distribution may, in some cases, be inevitable. That does not imply, however, that one group in society should carry the burden of change alone. Ostry emphasizes the need for a credible commitment to protect those left behind from globalization and reform: "Reforms have been enacted for many years, and government rhetoric has been that the potential to make everyone better off (from the larger pie)

will lead to broadly-shared improvements. But we know that in practice those displaced by reform have often not seen their situations addressed (for example, through the implementation of "trampoline" policies that allow them to bounce back in jobs that give them a decent income and the resulting dignity). If this is because of binding political constraints against effective pre-distribution and re-distribution policies, governments today will have to try much harder to regain credibility in the eyes of those who have been left behind." Perhaps saving capitalism and globalization for the winners may require much more attention by governments to those left behind, both ex ante in the reform choices pursued, and ex post through more aggressive use of fiscal redistribution.

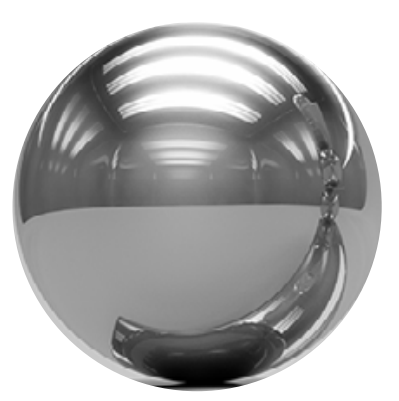




\section{TOBDT, QR NDT TOBDT...}
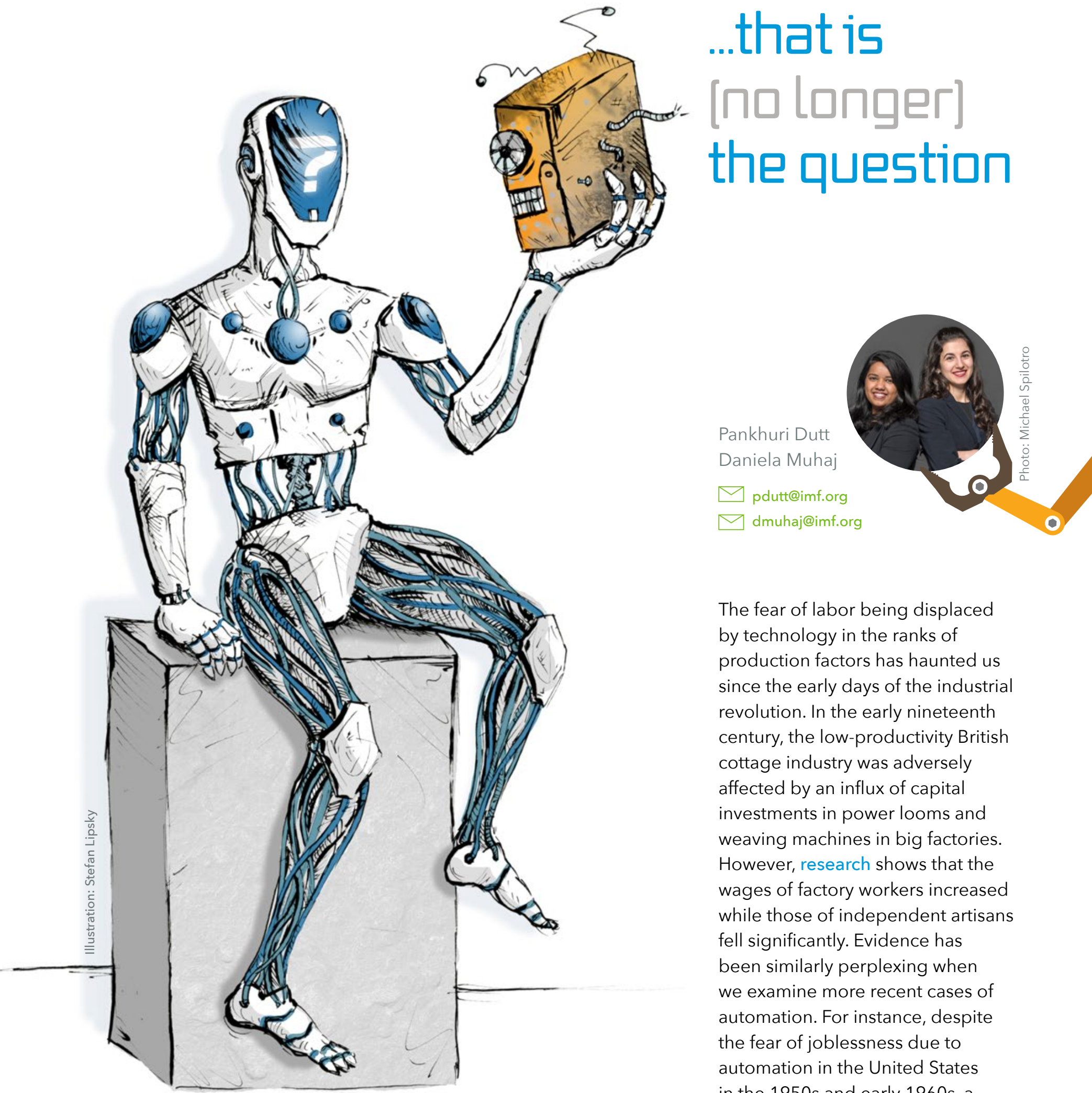

The fear of labor being displaced by technology in the ranks of production factors has haunted us since the early days of the industrial revolution. In the early nineteenth century, the low-productivity British cottage industry was adversely affected by an influx of capital investments in power looms and weaving machines in big factories. However, research shows that the wages of factory workers increased while those of independent artisans fell significantly. Evidence has been similarly perplexing when we examine more recent cases of automation. For instance, despite the fear of joblessness due to automation in the United States in the 1950s and early 1960s, a 
"It has become appallingly

obvious that our technology

has exceeded our humanity"

- Albert Einstein make a difference, there is a possibility that the magnitude of changes due to automation may be larger this time around." Some researchers believe there is a 50 percent chance that artificial intelligence will outperform all human tasks in 30-45 years. As jobs get displaced, inequality commission established to study the impact of automation on unemployment levels concluded that the level of unemployment was determined by the demand for goods and services in the economy, and not just automation alone.

Similarly, evidence from 28 OECD countries between 1970 and 2007 suggests that automation created more jobs but reduced labor's share of income.

Given the historical record of technological evolution, the question arises: will the current wave of technological changes associated with machine learning and artificial intelligence be any different? Helge Berger, who, along with Romain Duval helped write an IMF report for the G20 on the Future of Work, says "Though the new technologies are only beginning to

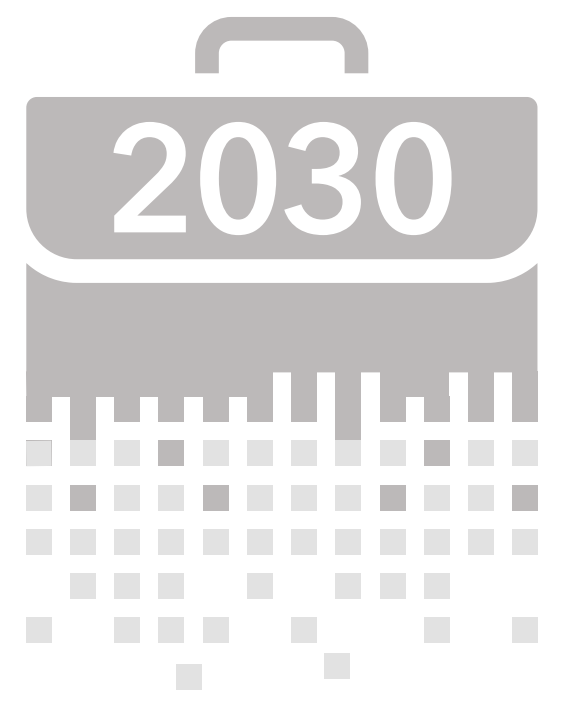

375 MILLION: number of workers that could lose their jobs by 2030 may rise. IMF research shows that robots will likely improve productivity, but, at the same time, might reduce the income share of labor and widen income inequality. Automation could also reduce incentives to outsource jobs from advanced countries to emerging economies, increasing inequality between those two groups.

Berger recognizes the difficulty of identifying specific disadvantages with certainty but he says one thing is for sure: "Automation will change the way we do things. The good news is that we have changed our ways before and have done well. So, why wouldn't we do it again?"

Automation will inevitably transform or eliminate hundreds of millions of jobs. According to McKinsey, automation may force up to 375 million workers globally to change their occupational group or learn new skills. The specifics and timing of this process, however, are highly disputed. To this end, Berger cautions, "It is tempting to limit technological progress to avoid associated negative impacts. However, this move has almost always backfired. We must allow the change to happen; facilitate it; help those who could be adversely affected; and improve our policy frameworks to embrace this change and harness its power. It is also the right thing to do." Historically, technological change has been associated with higher growth, higher employment, and higher

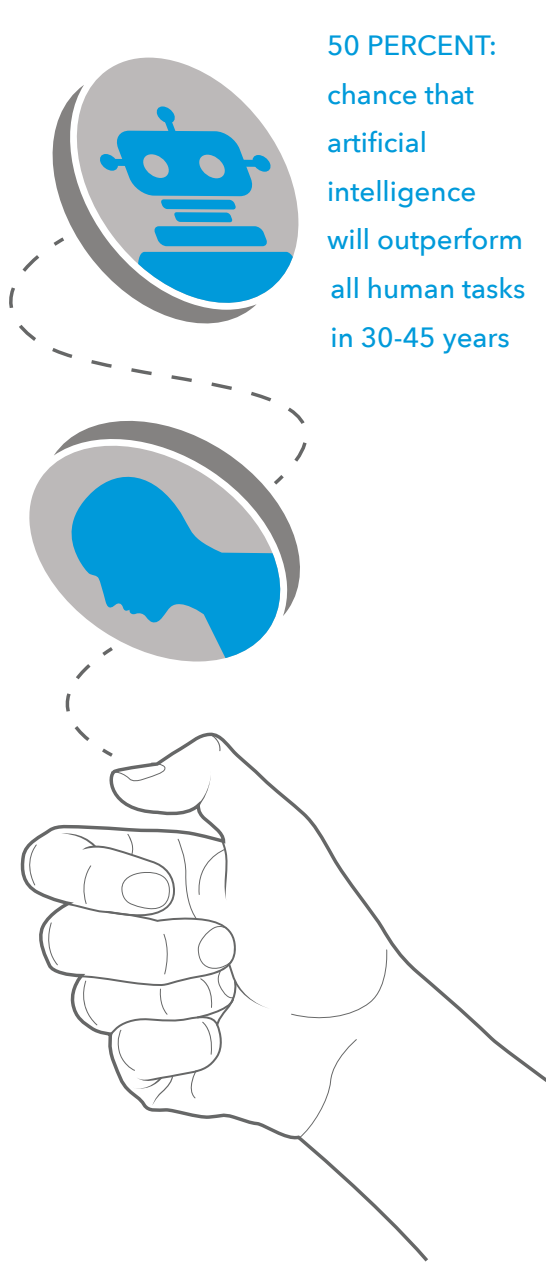

real wages. Berger believes that, while technology might displace jobs in low-skill sectors, it could also be used to augment labor in those sectors and increase productivity. It is difficult to prepare for and adapt to new practices associated with technological change, but as Einstein said, "the human spirit must prevail over technology."

Economic policies have a key role to play in managing this transition, mitigating the inequity-exacerbating impacts of technological change, and maintaining adequate aggregate demand growth to support new job creation. "Structural reforms free the economy to do new things," says Berger. Specifically, in the 


\section{ce}

\section{It is tempting to limit}

technological progress

to avoid associated

negative impact.

However, this move has

almost always backfired.
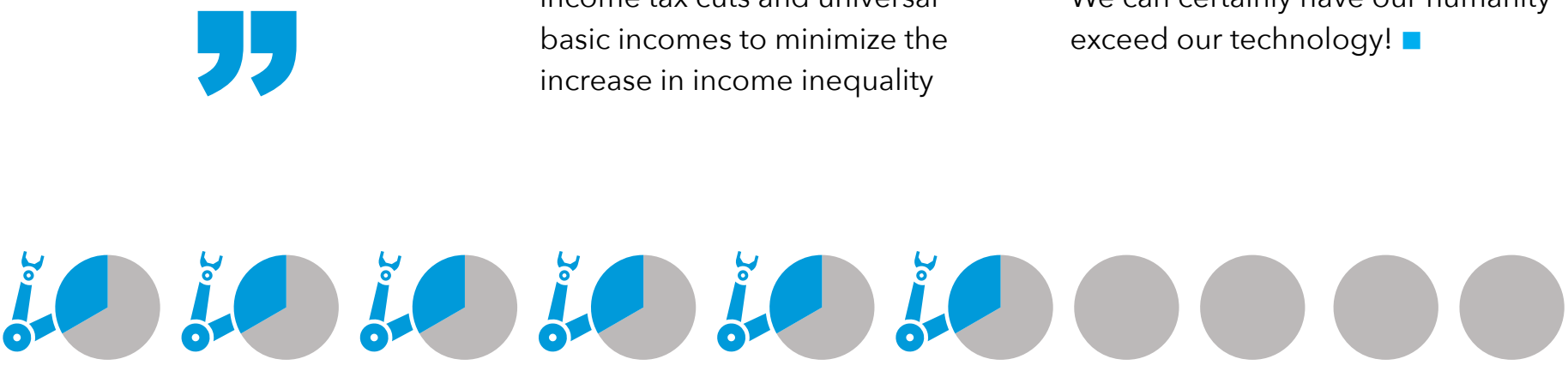

6 OF 10

current occupations that have more than a third of activities that are technically automatable

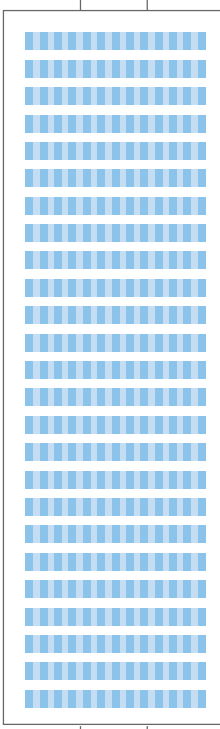

HIIIIIIIIIIII

Today

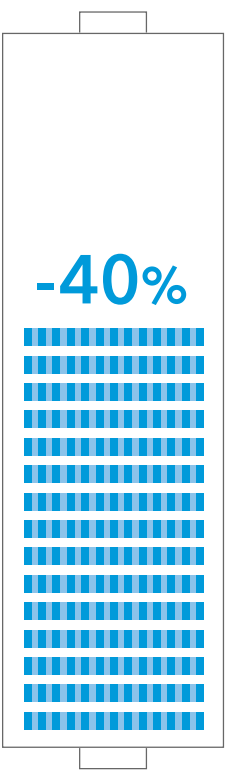

2068
40 PERCENT:

potential decline in the real

wage for low-skilled labor in

50 years 
definition, "big data" is often characterized by the three V'shigh volume, high velocity, and high variety. While the list of V's keeps increasing (i.e., veracity and volatility), competing definitions and understandings of the concept as well as its potential usage are also proliferating. Despite the confusion, one thing is clear: big data is here to stay. Every organization needs to understand what big data means to them, and how big data analytics can be deployed to enhance their work in a timely, efficient, and effective fashion.

Big data is a game changer for this century, what oil was to the last one (The Economist). Digital information is being extracted, refined, valued, bought, and sold in new and diverse ways, and everyone wants a piece of it (Gaining an Edge with Big Data). For the field of macroeconomics, there is exciting potential for how big data can produce new indicators, bridge time lags, support the forecasting of existing data sets, and provide innovative data sources to produce official statistics (IMF Staff Discussion Note). Public sector institutions and organizations have an interest in using big data and modern technologies to inform policy making. Here at the IMF, some of the applications of big data concern the assessment of competitiveness in the tourism sector through the A Week at the Beach Index, monitoring global financial flows and correspondent banking relationships through SWIFT data, and evaluating firm behavior based on Orbis data. Central Banks are using big data as an input for forecasting and nowcasting tools to support macroeconomic and financial stability assessments, assess the impact of policy communication and expectations for policy decisions through text mining, and collect information on, among other things, prices, fiscal indicators, and granular credit data. To harness the power of big data for policymaking, a holistic understanding of the opportunities must be accompanied by a thorough evaluation of the challenges and limitations that come with it.

Big data comes with big challenges. For policymaking applications, the quality assessment of indicators derived from big data is paramount, despite the strong demand for timely and granular data. "Big data poses a considerable legal challenge and requires specialized training that goes well beyond established econometric and statistical methods. The real challenge rests in assuring that the quality of the results is rigorous and credible so it can inform sound policy insights," says Mamoon Saeed, a member of the IMF's Information Technology Department. Currently, the IMF is using big data to uncover important real-time trends and insights as opposed to causal inference. "A systematic use of big data in policy analysis requires rethinking the institutional governance of information technology, and revamping long-standing practices in acquiring, disseminating and analyzing information," adds Marco Marini, who is part of the IMF's Statistics Department. Such changes will include new legal agreements, adapting cloud storage and related big data platforms, and acquiring an expertise in data science and machine learning techniques.

The necessary skills will be acquired through a combination of training existing employees and hiring those with new skills.
In short, a big data practice for policy analysis and economic surveillance in the long term will tip the skill balance and change the future of work everywhere.

Amid exciting prospects and significant challenges, the question arises: Can international organizations and public institutions ride the big data wave? They can, but not if they go it alone or too late. Big data is a dynamic phenomenon, the systems and networks generating it are ever evolving, and related challenges, limitations, and opportunities are ever changing. Saeed reiterates that "the world around us is changing at a faster pace. Industries are pioneering innovative ways of conducting business and shaping markets. Are we confident that our methods and indicators can cope with and capture these changes?" Organizations like the IMF recognize the need to go beyond individual and scattered applications of big data, build public-private partnerships to deliver measurable, scalable, and high-quality results, and facilitate peer learning across their membership. "Establishing sound partnerships, resolving legal issues, and acquiring the right skills and technologies are as important as statistical expertise, data representativeness, and methodological accuracy in harnessing the power of big data for better policymaking," conclude Cornelia Hammer and Diane Kostroch, both of whom are in the IMF's Statistics Department. The key to success lies in putting together a dynamic environment of people and processes that can take big data innovations forward and put them to work in a timely fashion without falling prey to bureaucratic inertia. 


\section{CAN \{UN\}HAPPINESS EXPLAIN MACROECONOMICS?}

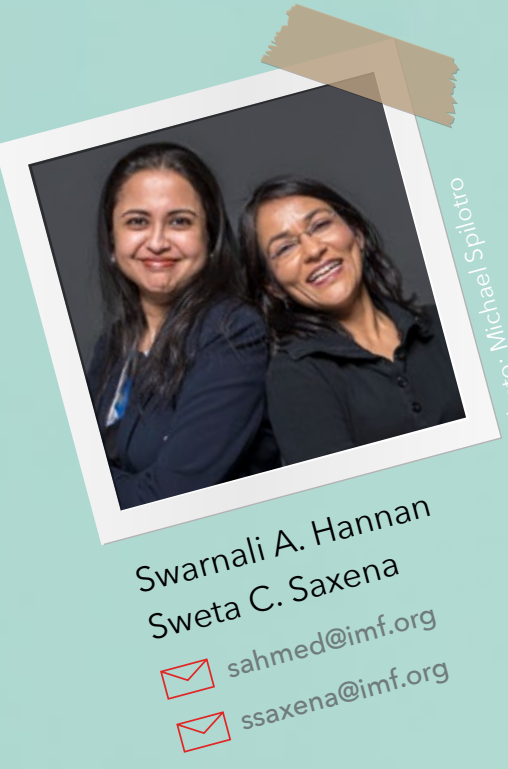

One of the most intriguing

puzzles of the modern era is the productivity slowdown in advanced economies, which started before the global financial crisis despite technological advancement. Recent policy discussions have focused on how to reverse that trend. What often goes unnoticed is how one's happiness affects productivity-as a sampling of more than 90 countries in Figure 1 shows, an increase in happiness can be associated with a rise in total factor productivity growth. The correlation becomes even stronger after controlling for income per capita, indicating that there is more to the association than the income factor. In a study conducted on 700 participants in the United Kingdom, Oswald and others (2015) find that happier individuals have approximately 12 percent greater productivity than a control group, with this higher productivity coming from increased efforts by workers.

What determines happiness or life satisfaction? Higher income per capita leads to higher happiness, but only up to a certain point (Layard 2005). At the same time, strong income growth does not necessarily translate into greater happiness. The World Happiness Report (2017) shows that, while GDP has multiplied more than fivefold over the past quarter century, subjective wellbeing in China fell for 15 consecutive years before finally beginning to recover, with the current levels still less than a quarter of a century ago. Indeed, the report also finds that factors contributing to happiness beyond income levels include a healthy life expectancy, social support (having someone to count on in times of trouble), trust (perceived absence of corruption in government and business), perceived freedom to make decisions, and generosity (recent donations).

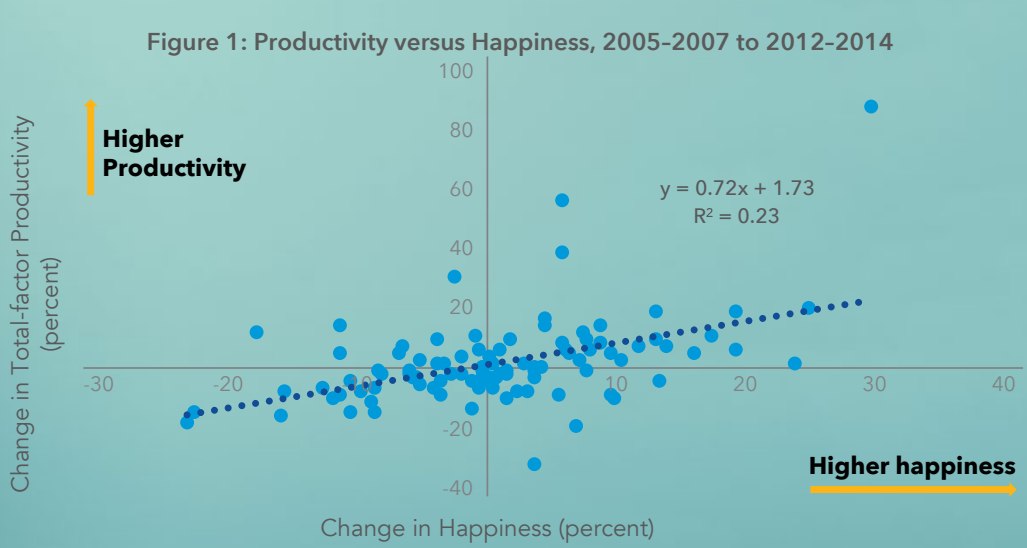

Source: Penn World Table (version 9.0), World Happiness Report (2015). 
In addition, happiness is determined by relative incomes. Whether you are happy with your income depends on two factors: what others get, and what you yourself are used to getting. This relationship between relative income and happiness is also manifested in the macroeconomic picture-people are happier in countries where inequality is declining (Figure 2). Not only is higher inequality associated with lower happiness, it can also hurt the level and sustainability of growth (Ostry and others, 2016) and thus generate further dissatisfaction with life.

The significance of indicators like life satisfaction and happiness in shaping social and macroeconomic outcomes is being gradually recognized, with international organizations such as the OECD and UNDP emphasizing the "quality of growth" that puts a person's wellbeing at the center of policy efforts. The IMF has also emphasized the need for inclusive growth-a broad sharing of the benefits of, and opportunities for, economic growth.

\section{According to social scientists,} approximately 50 percent of our happiness is determined by genes, 40 percent by our thoughts, actions, and behaviors, and only 10 percent by our circumstances (such as whether we are rich or poor, healthy or unhealthy, married or single). Hence, our own values can shape our level of happiness. As Adam Smith observed in the Theory of Moral Sentiment (1759): "How Selfish soever man be supposed, there are evidently some principles in his nature, which interest him in the fortune of others, and render their happiness necessary to him, though he derives nothing from it

\section{VIEW FROM THE VATICAN - THE 2018 WORLD HAPPINESS REPORT}

VATICAN CITY: The 2018 World

Happiness Report featured a

Nordic quinella, with Finland

topping Denmark for top place.

As in past years, the report underscored the ancient insight of sages like Aristotle-happiness depends less on money (at least beyond a certain level) and more on the quality of relationships, a sense of purpose, and the ability to make a social contribution. More technically, differences in happiness across countries (measured by Gallup surveys of subjective wellbeing, mainly the Cantril ladder of life satisfaction) can be explained by six factors-GDP per capita, healthy life expectancy, freedom to make life choices, social support, generosity, and trust. Importantly, social factors are more important than income in determining happiness. This is something that economists have largely forgotten, to the great detriment of the profession.
These insights were deployed to explain both why happiness is waning in the United States (declining trust and social cohesion) and why Latin America scores fairly highly, with the region's high quality of interpersonal relationships more than offsetting the high levels of inequality, crime, and corruption. This year's report focused mainly on migration, finding that the happiest countries also have some of the highest levels of immigration, that immigrants tend to be as happy as people born locally, and that happiness increases among immigrants and native-born alike when migrants are more accepted.

As a side note, the launch coincided with the death of the Pontifical Academy of Science's most illustrious academician, Stephen Hawking. It was quite a poignant experience to listen to recollections and look at the pictures of him meeting four popes over 40 years in that venue. RIP, Stephen.
Figure 2: Inequality versus Happiness, 2005-2007 to 2012-2014

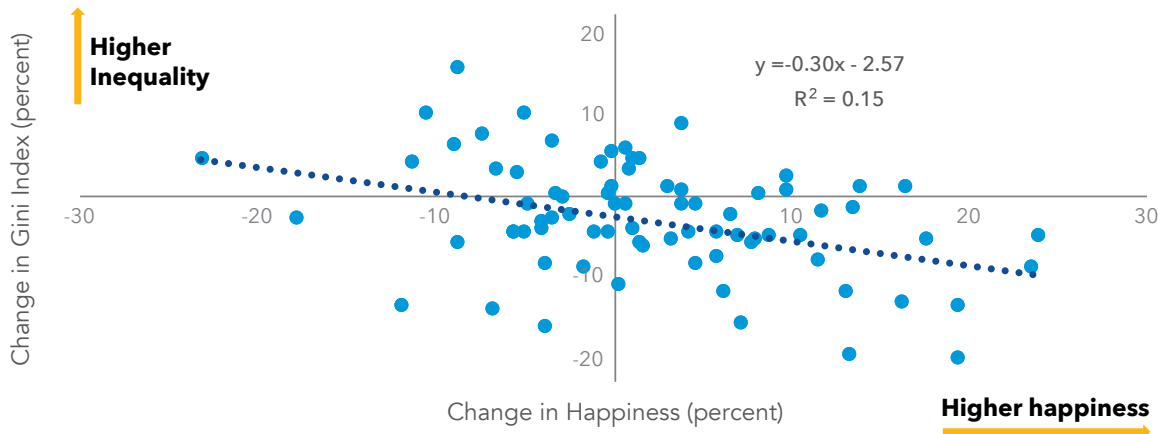

Source: World Bank, World Happiness Report (2015). except the pleasure of seeing it." Perhaps it may be time to move away from the external values emphasized in economics (such as competition, consumption, and profits) to internal values (such as cooperation, compassion, and altruism) professed by the likes of Aristotle and Buddha two and a half millennia ago. 


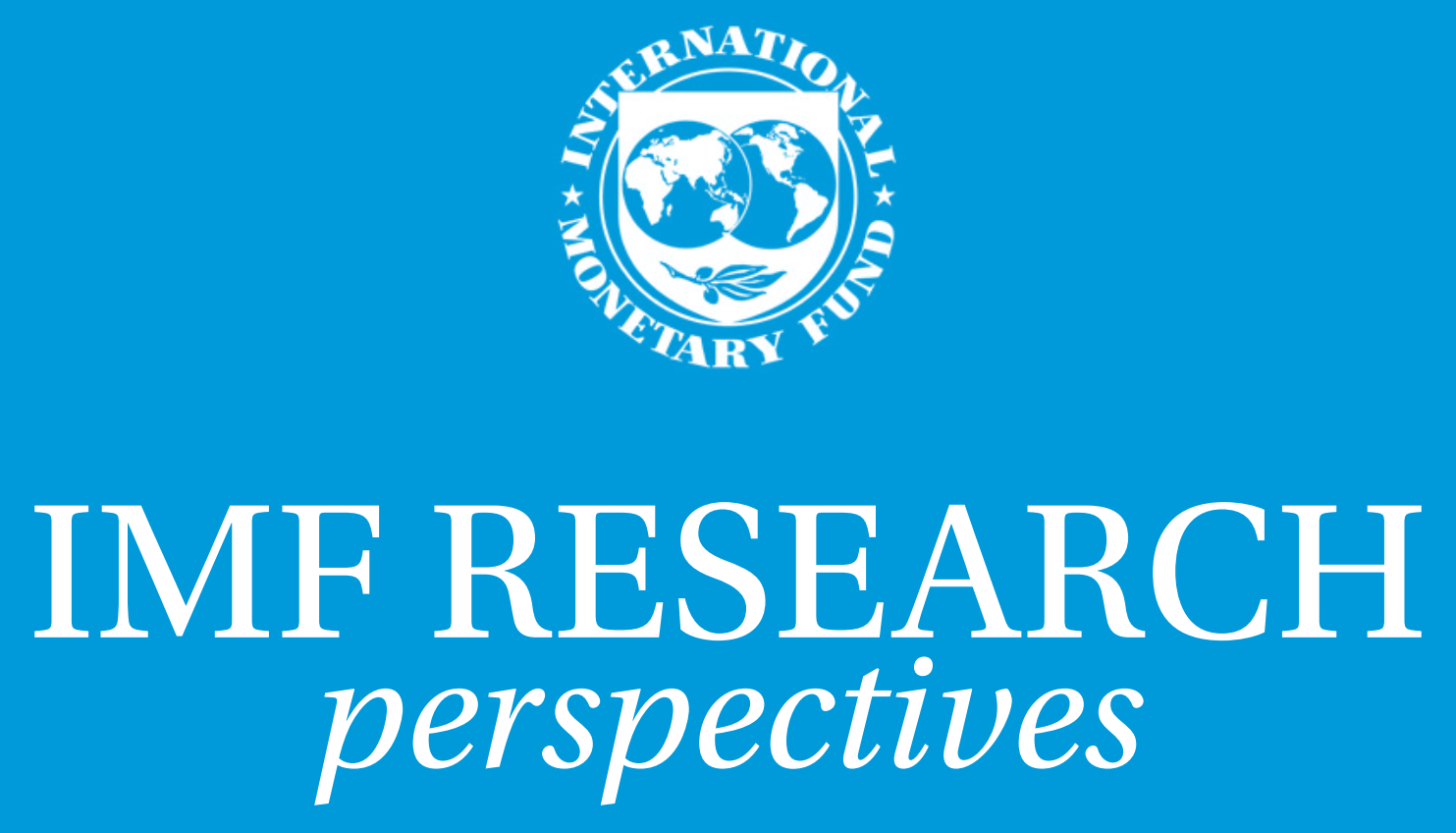

Learn more about IMF research at imf.org/external/research/

Visit IMF Economic Review, the official research journal of the IMF, at http://bit.ly/Palgrave-IMFER

Find IMF publications by visiting imf.org/pubs

Preview selected titles at eLibrary.imf.org/page/free

\section{Next edition: December 2018}

$$
\text { imf.org/researchbulletin }
$$

CInternational Monetary Fund. Not for Redistribution 